\title{
Front Matter: Volume 8741
}

, "Front Matter: Volume 8741," Proc. SPIE 8741, Unmanned Systems Technology XV, 874101 (14 June 2013); doi: 10.1117/12.2031794

SPIE Event: SPIE Defense, Security, and Sensing, 2013, Baltimore, Maryland, SPIE. United States 


\section{PROCEEDINGS OF SPIE}

\section{Unmanned Systems Technology XV}

Robert E. Karlsen

Douglas W. Gage

Charles M. Shoemaker

Grant R. Gerhart

Editors

1-3 May 2013

Baltimore, Maryland, United States

Sponsored and Published by

SPIE 
The papers included in this volume were part of the technical conference cited on the cover and title page. Papers were selected and subject to review by the editors and conference program committee. Some conference presentations may not be available for publication. The papers published in these proceedings reflect the work and thoughts of the authors and are published herein as submitted. The publisher is not responsible for the validity of the information or for any outcomes resulting from reliance thereon.

Please use the following format to cite material from this book:

Author(s), "Title of Paper," in Unmanned Systems Technology XV, edited by Robert E. Karlsen, Douglas W. Gage, Charles M. Shoemaker, Grant R. Gerhart, Proceedings of SPIE Vol. 8741 (SPIE, Bellingham, WA, 2013) Article CID Number.

ISSN: 0277-786X

ISBN: 9780819495327

Published by

SPIE

P.O. Box 10, Bellingham, Washington 98227-0010 USA

Telephone +1 3606763290 (Pacific Time) · Fax +1 3606471445

SPIE.org

Copyright (@ 2013, Society of Photo-Optical Instrumentation Engineers.

Copying of material in this book for internal or personal use, or for the internal or personal use of specific clients, beyond the fair use provisions granted by the U.S. Copyright Law is authorized by SPIE subject to payment of copying fees. The Transactional Reporting Service base fee for this volume is $\$ 18.00$ per article (or portion thereof), which should be paid directly to the Copyright Clearance Center (CCC), 222 Rosewood Drive, Danvers, MA 01923. Payment may also be made electronically through CCC Online at copyright.com. Other copying for republication, resale, advertising or promotion, or any form of systematic or multiple reproduction of any material in this book is prohibited except with permission in writing from the publisher. The CCC fee code is 0277-786X/13/\$18.00.

Printed in the United States of America.

Publication of record for individual papers is online in the SPIE Digital Library.

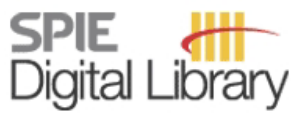

SPIEDigitalLibrary.org

Paper Numbering: Proceedings of SPIE follow an e-First publication model, with papers published first online and then in print and on CD-ROM. Papers are published as they are submitted and meet publication criteria. A unique, consistent, permanent citation identifier (CID) number is assigned to each article at the time of the first publication. Utilization of CIDs allows articles to be fully citable as soon as they are published online, and connects the same identifier to all online, print, and electronic versions of the publication. SPIE uses a six-digit CID article numbering system in which:

- The first four digits correspond to the SPIE volume number.

- The last two digits indicate publication order within the volume using a Base 36 numbering

system employing both numerals and letters. These two-number sets start with 00, 01, 02, 03, 04, 05, 06, 07, 08, 09, 0A, 0B ... 0Z, followed by 10-1Z, 20-2Z, etc.

The CID Number appears on each page of the manuscript. The complete citation is used on the first page, and an abbreviated version on subsequent pages. Numbers in the index correspond to the last two digits of the six-digit CID Number. 


\section{Contents}

vii Conference Committee
xi Introduction

\section{PERCEPTION AND NAVIGATION I}

874103 Dynamic, cooperative multi-robot patrolling with a team of UAVs [8741-3]

C. E. Pippin, H. Christensen, L. Weiss, Georgia Institute of Technology (United States)

874104 Vegetation versus man-made object detection from imagery for unmanned vehicles in offroad environments [8741-4]

J. Harguess, J. Larson, Space and Naval Warfare Systems Ctr. Pacific (United States)

874105 Landing spot selection for UAV emergency landing [8741-5]

P. T. Eendebak, A. W. M. van Eekeren, R. J. M. den Hollander, TNO (Netherlands)

874106 Feature detection and SLAM on embedded processors for micro-robot navigation [8741-45]

P. Robinette, T. R. Collins, Georgia Institute of Technology (United States)

\section{PERCEPTION AND NAVIGATION II}

874107 Robot mapping in large-scale mixed indoor and outdoor environments [8741-7] J. G. Rogers III, S. Young, J. M. Gregory, U.S. Army Research Lab. (United States); C. Nieto-Granda, H. I. Christensen, Georgia Institute of Technology (United States)

874108 Cooperative mobile agents search using beehive partitioned structure and Tabu Random search algorithm [8741-8]

S. Ramazani, D. L. Jackson, R. R. Selmic, Lovisiana Tech Univ. (United States)

874109 Cognitive patterns: giving autonomy some context [8741-9]

D. A. Dumond, W. Stacy, A. Geyer, J. Rousseau, M. Therrien, Aptima, Inc. (United States)

8741 OA Real-time adaptive off-road vehicle navigation and terrain classification [8741-11]

U. A. Muller, Net-Scale Technologies, Inc. (United States); L. D. Jackel, North-C Technologies, Inc. (United States); Y. LeCun, New York Univ. (United States); B. Flepp, NetScale Technologies, Inc. (United States)

$8741 \mathrm{OB} \quad$ Multi-robot exploration strategies for tactical tasks in urban environments [8741-12] C. Nieto-Granda, Georgia Institute of Technology (United States); J. G. Rogers III, U.S. Army Research Lab. (United States); H. I. Christensen, Georgia Institute of Technology (United States) 
8741 OC Semantic data association for planar features in outdoor 6D-SLAM using lidar [8741-13] C. Ulas, TÜBITAK (Turkey); H. Temeltas, Istanbul Technical Univ. (Turkey)

HUMAN-ROBOT INTERACTION AND COMMUNICATION

8741 OD Robust leader tracking from an unmanned ground vehicle [8741-14]

C. S. Monnier, S. German, A. Ostapchenko, Charles River Analytics, Inc. (United States)

8741 OE Multimodal interaction for human-robot teams [8741-15]

D. Burke, N. Schurr, J. Ayers, J. Rousseau, J. Fertitta, A. Carlin, D. Dumond, Aptima, Inc. (United States)

8741 OF An intuitive graphical user interface for small UAS [8741-16]

N. Stroumtsos, G. Gillbreath, S. Przybylski, Space and Naval Warfare Systems Ctr. Pacific (United States)

$87410 G$ Evaluating the presentation and usability of 2D and 3D maps generated by unmanned ground vehicles [8741-17]

J. Gregory, D. Baran, A. W. Evans III, U.S. Army Research Lab. (United States)

$8741 \mathrm{OH} \quad$ Evolution of a radio communication relay system [8741-18]

H. G. Nguyen, N. Pezeshkian, A. Hart, A. Burmeister, K. Holz, J. Neff, L. Roth, Space and Naval Warfare Systems Ctr. Pacific (United States)

8741 ol Multilateral haptics-based immersive teleoperation for improvised explosive device disposal [8741-52]

D. Erickson, Defence Research and Development Canada, Suffield (Canada);

H. Lacheray, J. Daly, Quanser Consulting Inc. (Canada)

\section{SESSION 6 INTELLIGENT BEHAVIORS}

8741 0J Position-adaptive MAV in emitter localization mission using RSSI and path loss exponent metrics [8741-20]

M. Gates, R. Selmic, Louisiana Tech Univ. (United States)

$87410 \mathrm{~K}$ Learning consensus in adversarial environments [8741-21]

K. G. Vamvoudakis, L. R. García Carrillo, J. P. Hespanha, Univ. of California, Santa Barbara (United States)

$8741 \mathrm{OL}$ Stable structures of coalitions in competitive and altruistic military teams [8741-22] M. Aurangzeb, The Univ. of Texas at Arlington (United States); D. Mikulski, G. Hudas, U.S. Army Tank Automotive Research, Development and Engineering Ctr. (United States); F. L. Lewis, The Univ. of Texas at Arlington (United States); E. Gu, Oakland Univ. (United States)

8741 OM Adaptive neural network consensus based control of robot formations [8741-23] H. M. Guzey, J. S., Missouri Univ. of Science and Technology (United States) 
8741 ON Maintaining robust connectivity in heterogeneous robotic networks [8741-24]

P. Cruz, R. Fierro, The Univ. of New Mexico (United States); W. Lu, S. Ferrari, Duke Univ.

(United States)

\section{ROBOTICS CTA I}

874100 Common world model for unmanned systems [8741-25]

R. M. S. Dean, General Dynamics Robotic Systems (United States)

8741 OP Using expectations to monitor robotic progress and recover from problems [8741-26]

U. Kurup, C. Lebiere, A. Stentz, M. Hebert, Carnegie Mellon Univ. (United States)

$87410 Q \quad$ Terrain identification for RHex-type robots [8741-27]

C. Ordonez, J. Shill, Florida State Univ. (United States); A. Johnson, Univ. of Pennsylvania (United States); J. Clark, E. Collins, Florida State Univ. (United States)

8741 OR An architecture for online semantic labeling on UGVs [8741-28]

A. Suppé, L. Navarro-Serment, D. Munoz, D. Bagnell, M. Hebert, Carnegie Mellon Univ. (United States)

\section{ROBOTICS CTA II}

8741 OT Performance of a scanning laser line striper in outdoor lighting [8741-30]

C. Mertz, Carnegie Mellon Univ. (United States)

8741 OU Visual and tactile interfaces for bi-directional human robot communication [8741-31]

D. Barber, S. Lackey, L. Reinerman-Jones, Univ. of Central Florida (United States); I. Hudson,

U.S. Army Research Lab. (United States)

8741 OV Dynamic whole-body robotic manipulation [8741-32]

Y. Abe, B. Stephens, M. P. Murphy, A. A. Rizzi, Boston Dynamics (United States)

$8741 \mathrm{OW} \quad$ Free-standing leaping experiments with a power-autonomous elastic-spined quadruped [8741-33]

J. L. Pusey, U.S. Army Research Lab. (United States); J. M. Duperret, Univ. of Pennsylvania

(United States); G. C. Haynes, Carnegie Mellon Univ. (United States); R. Knopf,

D. E. Koditschek, Univ. of Pennsylvania (United States)

\section{SPECIAL TOPICS I}

8741 OX Collaborative experiments of small autonomous systems at the SOURCE ATO capstone experiment [8741-34]

J. Gregory, D. Baran, J. Rogers III, J. Fink, J. Delmerico, U.S. Army Research Lab. (United States) 
8741 OY Achieving integrated convoys: cargo unmanned ground vehicle development and experimentation [8741-35]

N. Zych, Oshkosh Corp. (United States); D. Silver, D. Stager, C. Green, T. Pilarski, Carnegie Mellon Univ. (United States); J. Fischer, Oshkosh Corp. (United States)

$87410 Z$ UGV: security analysis of subsystem control network [8741-42]

S. Abbott-McCune, P. Kobezak, J. Tront, R. Marchany, A. Wicks, Virginia Polytechnic Institute and State Univ. (United States)

874110 A preliminary cyber-physical security assessment of the Robot Operating System (ROS) [8741-41]

J. McClean, Harvard Univ. (United States); C. Stull, C. Farrar, D. Mascareñas, Los Alamos National Lab. (United States)

874111 Development of a non-contextual model for determining the autonomy level of intelligent unmanned systems [8741-38]

P. J. Durst, W. Gray, U.S. Army Engineer Research and Development Ctr. (United States); M. Trentini, Defence Research and Development Canada, Suffield (Canada)

874112 Simple but novel test method for quantitatively comparing robot mapping algorithms using SLAM and dead reckoning [8741-39]

N. S. Davey, Montgomery Blair High School (United States); H. Godil, Univ. of Maryland, College Park (United States)

POSTER SESSION

874118 An open-source scheduler for small satellites [8741-44]

D. Torgerson, J. Straub, A. Mohammad, C. Korvald, D. Limesand, Univ. of North Dakota (United States)

874119 Human and tree classification based on a model using 3D ladar in a GPS-denied environment [8741-46]

K. Cho, Univ. of Science \& Technology (Korea, Republic of); S.-H. Baeg, S. Park, Korea Institute of Industrial Technology (Korea, Republic of)

8741 1 A Universal framework for unmanned system penetration testing [8741-47]

P. Kobezak, S. Abbot-McCune, J. Tront, R. Marchany, A. Wicks, Virginia Polytechnic Institute and State Univ. (United States)

Author Index 


\title{
Conference Committee
}

\author{
Symposium Chair
}

Kenneth R. Israel, Major General (USAF Retired) (United States)

Symposium Cochair

David A. Whelan, Boeing Defense, Space, and Security (United States)

Conference Chairs

Robert E. Karlsen, U.S. Army Tank Automotive Research, Development and Engineering Center (United States)

Douglas W. Gage, XPM Technologies (United States)

Charles M. Shoemaker, U.S. Army Communications-Electronics Research Development and Engineering Command (United States)

Grant R. Gerhart, U.S. Army Tank-Automotive Research,

Development, and Engineering Center, Retired (United States)

Conference Program Committee

Jonathan A. Bornstein, U.S. Army Research Laboratory (United States) Jared Giesbrecht, Defence Research and Development Canada, Suffield (Canada)

Frank L. Lewis, The University of Texas at Arlington (United States)

Larry H. Matthies, Jet Propulsion Laboratory (United States)

Paul L. Muench, U.S. Army Tank Automotive Research, Development and Engineering Center (United States)

Hoa G. Nguyen, Space and Naval Warfare Systems Center Pacific (United States)

James L. Overholt, U.S. Army Tank Automotive Research,

Development and Engineering Center (United States)

Mike Perschbacher, RovnoTech (United States)

Marc Raibert, Boston Dynamics (United States)

Klaus-Juergen Schilling, Julius-Maximilians-Universität Würzburg (Germany)

Anthony Stentz, Carnegie Mellon University (United States)

Gary Witus, Turing Associates, Inc. (United States)

Brian M. Yamauchi, iRobot Corporation (United States) 


\section{Session Chairs}

1 Open Architecture (OA)/Open Business Model (OBM) Systems: Joint Session with Conferences 8741 and 8754

Raja Suresh, General Dynamics Advanced Information Systems (United States)

Douglas W. Gage, XPM Technologies (United States)

2 Perception and Navigation I

Douglas W. Gage, XPM Technologies (United States)

3 Perception and Navigation II

Camille S. Monnier, Charles River Analytics, Inc. (United States)

4 MAST: Software: Joint Session with Conferences 8725 and 8741

Paul D. Samuel, Daedalus Flight Systems, LLC (United States)

5 Human-Robot Interaction and Communication

Hoa G. Nguyen, Space and Naval Warfare Systems Center Pacific (United States)

Camille Monnier, Charles River Analytics, Inc. (United States)

6 Intelligent Behaviors

Kyriakos G. Vamvoudakis, University of California, Santa Barbara (United States)

Frank L. Lewis, The University of Texas at Arlington (United States)

7 Robotics CTA I

Robert R. Mitchell, General Dynamics Robotic Systems (United States)

Jonathan A. Bornstein, U.S. Army Research Laboratory (United States)

8 Robotics CTA II

Robert R. Mitchell, General Dynamics Robotic Systems (United States)

Jonathan A. Bornstein, U.S. Army Research Laboratory (United States)

9 Special Topics I

Douglas W. Gage, XPM Technologies (United States)

10 Special Topics II

Douglas W. Gage, XPM Technologies (United States) 
Panel Discussion on Open Architecture (OA)/Open Business Model (OBM) Systems: Joint Panel with Conferences 8741 and 8754

Raja Suresh, Moderator, General Dynamics Advanced Information Systems (United States)

Bobby Junker, Office of Naval Research (United States)

Carlo Zaffanella, General Dynamics Advanced Information Systems (United States)

Howard Reichel, In-Depth Engineering Corporation (United States)

Nick Guertin, U.S. Navy (United States) 
Proc. of SPIE Vol. $8741874101-10$

Downloaded From: https://www.spiedigitallibrary.org/conference-proceedings-of-spie on 26 Apr 2023 Terms of Use: https://www.spiedigitallibrary.org/terms-of-use 


\section{Introduction}

The Unmanned Systems Technology XV Conference consisted of 10 sessions that spanned three days and were devoted to many areas of robotics. Although the vast majority of fielded unmanned systems are teleoperated, interest in autonomy has been especially high in recent years, perhaps because of recent advances that bring autonomous platforms from the laboratory to commercial viability. This year's conference submissions show that progress is being made along the entire autonomy spectrum, from improvements in teleoperation to teams of autonomous robots. And different levels of autonomous capability allow (or require) different methods for human/robot and robot/robot interactions. Progress is also being made in terms of alternative platform development, including robotic insects, birds, dogs, and mules. It is certainly an interesting time to be involved with unmanned systems!

The opening session on Wednesday was Open Architecture (OA)/Open Business Model (OBM) Systems, which was a joint session with Open Architecture/Open Business Model Net-Centric Systems and Defense Transformation 2013, Conference 8754. Since robotics is a relatively new industry, it currently struggles with issues of interoperability and lacks widespread open standards. This session consisted of three keynotes and a panel discussion on this issue. The Perception and Navigation I session included papers on navigation and landing of unmanned air vehicles (UAVs), object detection, and navigation and localization for micro-scale platforms. The Perception and Navigation II session continued with papers on robot mapping experiments in large indoor and outdoor environments, UAV search patterns, navigation through knowledge reasoning and machine learning, and simultaneous localization and mapping (SLAM) with planar features. Perception and intelligence continue to be some of the thornier problems facing autonomous vehicles, especially in the ground domain.

The Thursday morning session was a joint session with Conference 8725, Microand Nanotechnology Sensors, Systems, and Applications V, and consisted of work performed under the Army Research Laboratory's (ARL) Micro-Autonomous Systems and Technology (MAST) Collaborative Technology Alliance (CTA). The papers described locomotion, sensing, and processing for bio-inspired micro-sized flapping wing air vehicles and legged ground vehicles. These smaller-sized platforms require paradigm shifts since many unmanned technologies do not scale well with size. The afternoon's Human-Robot Interaction (HRI) and Communication Session described work in vision-based dismounted leader/follower, multi-modal communication, map presentation experiments, communication relays, and control of a multi-armed ground vehicle. HRI is a key area for tightly integrating robots into a squad or for managing a distant team of unmanned vehicles, and will require methods beyond the current laptop and joystick controlling every action. The interplay between HRI and autonomous 
functionality will be increasingly important in the coming years, as the commercial automobile industry has learned. To take full advantage of a team of autonomous assets, they also need to interact effectively amongst themselves. With that in mind, the final session of the day, Intelligent Behaviors, consisted of papers discussing research involving teams of autonomous robots, including communication-aware navigation and control, consensus learning, formation control, and coalition building.

Friday began with two sessions from ARL's Robotics CTA, which is performing research to enable squad-level robot team members. The papers described current research on building common world models, cognitive architectures, semantic labeling of imagery, outdoor laser-based structured light sensor, terrain understanding for legged robots, gesture recognition and tactile displays, wholebody manipulation, and quadruped jumping. The conference concluded with the Special Topics Session, which included papers on a variety of areas, such as experiments in autonomy with small robot navigation and large vehicles in convoys, testing of mapping algorithms, alternative levels of autonomy level, and cyber security for unmanned systems.

This year's conference covered a wide swath of unmanned systems technologies and demonstrates why robotics is such an exciting area. We want to especially thank those that stepped forward and assisted in making this a successful conference in spite of the issues with government funding and conference attendance regulations. We hope you enjoy these proceedings and are able to attend the conference next year.

\section{Robert E. Karlsen Douglas W. Gage Charles M. Shoemaker Grant R. Gerhart}

